\title{
Kerangka Konsep Pengembangan Kurikulum Berbasis Multiple Intelligence pada Pendidikan Anak Usia Dini
}

\author{
Mila Faila Shofa
}

Received: 2982017 / Accepted: 20112017 / Published online: 25122017

(c) 2017 Association of Indonesian Islamic Kindergarten Teachers Education Study Program

\begin{abstract}
The aims of this article are to (1) describes the concept of M ultiple Intelligence-based curriculum development in Early Childhood Education, (2) describes the implications of curriculum-based learning at the M ultiple Intelligence in Early Childhood Education. Data acquisition method of this article is through literature and empirical experience of the author. The results of this article explains that exposure to develop the Multiple Intell igence-based curriculum, teachers and school curriculum development team can put the idea of Multiple Intelligence manner. Multiple Intelligence curriculum can be reflected with some learning approaches, including approaches based learning center. M ultiple Intelligence curriculum can be organized with the 2013 early childhood curriculum where the curriculum structure is the organization of core competencies, basic competencies, and learning the charge with each of multiple intelligences. Implications of M ultiple Intelligence learning curriculum through three stages namely planning, implementation, and evaluation. Learning plan includes lesson plans based on M ultiple Intelligence W eekly and Daily Lesson Plan-Based M ultiple Intelligence. The learning center is implemented through activities in accordance with the linguistic intelligence center, musical center, visual-spatial center, kinestetic center, logical-mathematical center, center intrapersonal, interpersonal center, naturalist center, and existentialist center. Rating is based on the development of students' achievement indicators for each intell igenceat every age.
\end{abstract}

Keywords development, curriculum, multiple intelligence, early childhood education

\begin{abstract}
Abstrak Penulisan artikel ini bertujuan untuk (1) memaparkan tentang konsep pengembangan kurikulum berbasis M ultiple Intelligence pada Pendidikan Anak U sia Dini, (2) memaparkan implikasi kurikulum berbasis Multiple Intelligence dalam pembelajaran pada Pendidikan Anak U sia Dini. M etode pemerolehan data dari artikel ini adalah melalui studi pustaka dan pengalaman empiris dari penulis. $\mathrm{H}$ asil pemaparan artikel ini menjelaskan bahwa untuk mengembangkan kurikulum berbasis Multiple Intelligence, guru dan tim pengembang kurikulum sekolah dapat memakai ide dari M ultiple Intelligencedengan cara beragam. Kurikulum M ultiple Intelligence dapat direfleksikan dengan beberapa pendekatan pembelajaran termasuk pendekatan pembelajaran berbasis center. Kurikulum Multiple Intelligence dapat diorganisasikan dengan kurikulum 2013 PAUD dimana struktur kurikulum merupakan pengorganisasian kompetensi inti, kompetensi dasar, dan muatan pembelajaran dengan masing-masing kecerdasan majemuk. Implikasi kurikulum Multiple Intelligence dalam pembelajaran melalui 3 tahap yakni perencanaan, pelaksanaan, dan evaluasi pembelajaran. Perencanaan pembelajaran meliputi Rencana Pelaksanaan Pembelajaran Mingguan berbasis Multiple Intelligence dan Rencana Pelaksanaan Pembelajaran $\mathrm{H}$ arian Berbasis Multiple Intelligence. Adapun pembelajaran dilaksanakan
\end{abstract}


melalui kegiatan di center sesuai dengan kecerdasan yakni linguistic center, musical center, visual-spasial center, kinestetic center, logical-mathematical center, intrapersonal center, interpersonal center, naturalis center, dan eksistensialis center. Penilaian perkembangan anak didik didasarkan pada indikator pencapaian tiap-tiap kecerdasan pada tiap usia.

Kata Kunci: pengembangan, kurikulum, multiple intelligence, pendidikan anak usia dini

\section{Pendahuluan}

Pendidikan A nak U sia Dini (PAUD) adalah pendidikan untuk anak usia 0-6 tahun dengan tujuan untuk memberikan stimulasi pertumbuhan dan perkembangan anak. Dengan adanya stimulasi anak usia dini diharapkan mampu mempersiapkan diri untuk pendidikan di jenjang berikutnya. Selain itu potensi dan bakat anak akan tergali menjadi suatu kemampuan yang nyata. Stimulasi merupakan sebuah proses yang terencana, dilakukan terus menerus untuk mencapai tujuan yakni pertumbuhan dan perkembangan yang optimal.

Pemberian stimulasi/ rangsangan kepada anak usia dini perlu direncanakan dengan baik melalui kurikulum. M enurut U ndang-U ndang N omor 20 tahun 2003 tentang Sistem Pendidikan Nasional, kurikulum adalah seperangkat rencana dan pengaturan mengenai tujuan, isi, dan bahan ajar, serta cara yang digunakan sebagai pedoman penyelenggaraan kegiatan pembelajaran untuk mencapai tujuan pendidikan tertentu. Berdasarkan pengertian tersebut kurikulum merupakan pedoman yang digunakan guru untuk melaksanakan pembelajaran. Pelaksanaan pembelajaran harus direncanakan dan dapat mencapai tujuan pendidikan yang ditetapkan, oleh karena itu kurikulum harus dikembangkan sesuai dengan karakteristik, kebutuhan dan perkembangan seluruh kecerdasan peserta didik.

Kecerdasan sesuai dengan teori Howard Gardner merupakan kemampuan yang dimiliki oleh seseorang untuk memecahkan permasalahan dan menciptakan sebuah produk. Kecerdasan tidak hanya dipengaruhi oleh faktor bawaan tetapi lebih banyak dipengaruhi oleh lingkungan dan dapat dipelajari melalui interaksi dengan lingkungan. Gardner membagi kecerdasan menjadi 9 kecerdasan yakni kecerdasan linguistik, kecerdasan logis matematis, kecerdasan visual spasial, kecerdasan kinestetik, kecerdasan naturalis, kecerdasan musical, kecerdasan intrapersonal, kecerdasan interpersonal, dan kecerdasan eksistensial. Kurikulum disekolah pada umumnya hanya menekankan pada kecerdasan linguistik dan kecerdasan logika matemaika saja, sedangkan kecerdasan yang lain tidak dianggap sebagai hal yang penting. Oleh karena itu, kurikulum PAUD hendaknya dikembangkan sesuai dengan teori multiple intelligence sehingga dapat memfasilitasi kecerdasan yang dimiliki oleh setiap anak.

Penelitian Sibel \& Ibrahim Ali (2013) tentang pengaruh pembelajaran berbasis multiple intelligence terhadap prestasi dan pengetahuan siswa memaparkan bahwa pembelajaran dengan berbasis multiple intelligence lebih efektif dibanding pembelajaran konvensional dalam meningkatkan prestasi dan pengetahuan siswa. Berdasarkan hasil penelitian diatas pengembangan kurikulum PAUD berbasis multiple intelligence diharapkan dapat menyelenggarakan pembelajaran yang lebih efektif. Berbicara tentang kurikulum PAUD tidak lepas dari konsep Developmentally A ppropriate Practice (DAP). Konsep dari DAP memiliki tiga dimensi, yaitu: patut menurut usia (age appropriate), patut menurut anak sebagai individu yang unik (individual appropriate), dan patut menurut lingkungan dan budaya (culture appropriate) (Kostelnik: 1999). 


\section{Pembahasan}

\section{Pengertian kurikulum}

Banyak pendapat yang mengartikan kurikulum. Kurikulum bisa diartikan sebagai semua pengalaman yang diseluruh pengalaman yang akan terjadi di sekolah; sebuah rencana tertulis dari progran pembelajaran; seperangkat rencana program pendidikan yang berisi berbagai bahan ajar dan pengalaman belajar, kurikulum sebagai pedoman pembelajaran. Dari berbagai pendapat tentang pengertian kurikulum diatas dapat disimpulkan bahwa kurikulum adalah seperangkat program pendidikan yang berisi tujuan, isi/bahan ajar, metode, serta evaluasi yang digunakan sebagai pedoman pembelajaran pada pendidikan anak usia dini. Salah satu fungsi kurikulum ialah sebagai alat untuk mencapai tujuan pendidikan yang pada dasarnya kurikulum memiliki komponen pokok dan komponen penunjang yang saling berkaitan dan berinteraksi satu sama lainnya dalam rangka mencapai tujuan tersebut. Komponen merupakan satu sistem dari berbagai komponen yang saling berkaitan dan tidak bisa dipisahkan satu sama lainnya, sebab kalau satu komponen saja tidak ada atau tidak berjalan sebagaimana mestinya.

Nugraha (2008) mengemukakan komponen kurikulum, yakni tujuan, bahan ajar/materi, metode, dan evaluasi . Lebih jelas dapat dilihat dari gambar berikut.

Gambar 1.

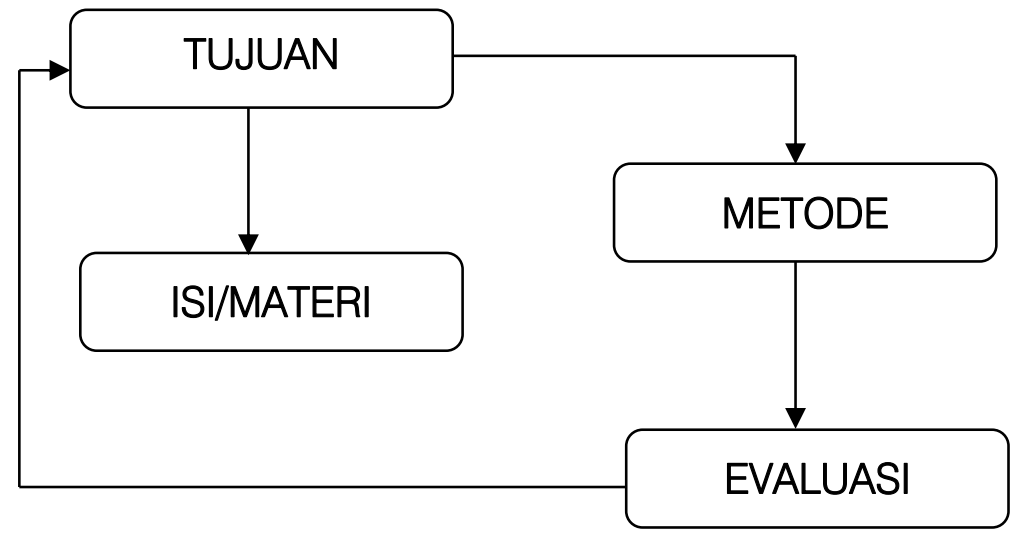

Komponen Kurikulum

\section{Konsep MultipleIntelligence}

Teori Multiple Intelligence diprakarsai oleh H oward Gardner, ia berpendapat bahwa tidak ada manusia yang tidak cerdas, artinya setiap manusia cerdas dibidangnya masing-masing yang selanjutnya kecerdasan ini dikenal dengan multipleintelligence. Berikut ini kecerdasan pada anak usia dini yang didasarkan pada teori multiple intelligence.

1. Kecerdasan bahasa, Kecerdasan ini erat hubunganya dengan kata-kata, baik lisan maupun tertulis beserta aturan-aturannya. Kecerdasan bahasa dapat diartikan sebagai kemampuan menyelesaikan masalah dan menciptakan sesuatu dengan menggunakan bahasa secara efektif, baik lisan maupun tertulis (M usfiroh 2008, 2-3).

2. Kecerdasan logika matematika, kecerdasan ini berkaitan dengan kemampuan mengolah angka atau kemahiran menggunakan logika. Kecerdasan logika matematika didefinisikan sebagai kemampuan menggunakan angka dengan baik dan melakukan penalaran yang benar. Kemampuan ini meliputi kemampuan menyelesaikan masalah, mengembangkan masalah, 
dan menciptakan sesuatu dengan angka dan penalaran (A mstrong 1999 dalam Musfiroh 2008, 3.3).

3. Kecerdasan musikal, kecerdasan ini berkaitan dengan kemampuan menangkap bunyi-bunyi, membedakan, menggubah, dan mengekspresikan dan melalui bunyi atau suara yang bernada dan berirama. Kecerdasan ini meliputi kepekaan pada irama, melodi, dan warna suara.

4. Kecerdasan kinestetik, kecerdasan ini berkaitan dengan kemampuan menggunakan gerak seluruh tubuh untuk mengekspresikan ide dan perasaannya serta keterampilan mempergunakan tangan untuk mencipta atau mengubah sesuatu. Kecerdasan ini meliputi kemampuan fisik yang spesifik, seperti koordinasi, keseimbangan, keterampilan, kekuatan, kelenturan, kecepatan dan keakuratan menerima rangsang, sentuhan dan tekstur. Kecerdasan kinestetik didefinisikan sebagai kemampuan menggunakan seluruh tubuh untuk mengekspresikan ide dan perasaan serta keterampilan menggunakan tangan untuk menciptakan atau mengubah sesuatu (A mstrong 2002 dalam M usfiroh 2008).

5. Kecerdasan visual-spasial, kecerdasan ini berkaitan dengan kemampuan menangkap warna, arah, dan ruang secara akurat serta mengubah penagkapanya tersebut ke dalam bentuk lain seperti dekorasi arsitektur, lukisan, patung. M enurut A mrtrong 2003 (dalam M usfiroh 2008) kecerdasan visual spasial didefinisikan sebagai kemampuan mempersepsi dunia visual-spasial secara akurat serta mentransformasikan persepsi visual-spasial tersebut dalam berbagai bentuk.

6. Kecerdasan interpersonal, kecerdasan ini melibatkan kemampuan untuk memahami dan bekerjasama dengan orang lain. Kecerdasan ini melibatkan banyak kecakapan, yakni kemampuan berempati kepada orang lain, kemampuan mengorganisasi sekelompok orang menuju ke tujuan bersama, kemampuan mengenali dan membaca pikiran orang lian, mkemampuan berteman atau menjalin kontak (Amstrong, dalam M usfiroh 67, 2015)

7. Kecerdasan intrapersonal, kecerdasan ini berkaitan dengan aspek internal dalam diri seseorang, seperti perasaan hidup, rentang emosi, kemampuan untuk membedakan emosiemosi, menandainya, dan menggunakannya untuk memahami dan membimbing tingkah laku sendiri.

8. Kecerdasan naturalis, kecerdasan ini berkaitan dengan kemahiran dalam mengenali dan mengklasifikasikan flora dan fauna dalam lingkungannya.

9. Kecerdasan eksistensialis, kecerdasan ini merupakan kemampuan menempatkan diri sendiri dalam jangkauan wilayah kosmos yang terjauh dan dalam ciri menusiawi yang paling eksistensial (Amstrong, 1999 dalam M usfiroh, 2008). Kecerdasan eksistensialisjuga berkaitan dengan kemampuan merasakan, memimpikan dan menjadi pemikir.

\section{Kurikulum PAUD Berdasarkan Prinsip DAP}

DAP (D evelopmentally Appropriate Practice) dicetuskan oleh NAEYC (National Association for the Education of Young Children) pada tahun 1998. NAEYC lahir dari Departemen Pendidikan USA untuk merumuskan kurikulum dan program yang sesuai dengan Anak Usia Dini. NAEYC berhasil mensosialisasikan tentang kurikulum untuk PAUD karena DAP memberikan panduan pembelajaran berdasarkan jenjang usia anak.

M enurut Sue Bredecamp (2006) DAP adalah perencanaan yang bermakna dan sesuai dengan perkembangan anak sebagai penerapan pengetahuan mengenai perkembangan anak dalam lembaga PAUD. Program pembelajaran yang direncanakan untuk Anak Usia Dini berdasarkan pengetahuan mengenai perkembangan anak. 
Menurut Sue Bredekamp (1987), konsep dari DAP memiliki dua dimensi, yaitu: patut menurut usia (age appropriate), patut menurut anak sebagai individu yang unik (individual appropriate). Gary Glassenapp (M egawangi, 2005: 5) menambahkan 1 dimensi lagi, yaitu: patut menurut lingkungan dan budaya (cultural appropriate).

Berdasarkan 3 dimensi DAP tersebut dapat dirumuskan Kurikulum PAUD sesuai dengan konsep DAP adalah isi kurikulum yanng mempersiapkan seluruh aspek perkembangan anak: fisik, emosi, sosial, linguistic, estetika, dan kognitif, kurikulum MI meliputi rentang cakupan isi yang luas, lintas disiplin yang relevan secara sosial, intelektual, maupun pengembangan kepribadian anak, Kurikulum dibangun atas dasar apa yang seharusnya diketahui dan dapat dilakukan anak-anak (stimulasi pengetahuan dasar) untuk disesuaikan dengan pembelajaran dalam penguasaan konsep-konsep maupun keterampilan (skills) yang baru.

\section{Kurikulum PAUD Berbasis Multiplelnteligence}

Berdasarkan pemaparan tentang konsep kurikulum, M ultiple Intelligence dan konsep DAP dapat disimpulkan bahwa pengembangan dan implikasi kurikulum berbasis Multiple Intelligence penting untuk diterapkan pada Pendidikan Anak Usia Dini. Kurikulum ini berusaha untuk menerapkan pembelajaran yang terpusat pada individu. Untuk mengembangkan kurikulum berbasis multiple intelligence, guru dan tim pengembang kurikulum sekolah dapat memakai ide dari multiple intelligence dengan cara beragam. Kurikulum multiple intelligence dapat direfleksikan dengan beberapa pendekatan pembelajaran termasuk pendekatan pembelajaran berbasis center. A dapun pengorganisasian kurikulum multiple intelligence dengan pendekatan pembelajaran berbasis center dapat dipaparkan sebagai berikut:

\section{Jenis Center Berbasis Multiplelntelligence}

1. Linguistic center. Beberapa menu pembelajaran/permainan yang dapat diimplementasikan dalam linguistik center, antara lain: permainan gambar, permainan tebak kata, permainan huruf yang sama, dan permainan menempel huruf.

2. Logical mathematical center. Beberapa menu pembelajaran/permainan yang dapat diimplementasikan dalam logical mathematical center, antara lain: permainan acak geometri, permainan menata balok, permainan tata angka, bermain ukuran, percobaan/eksperimen, dan permainan pola (warna, bentuk, ukuran).

3. Kinestetik center. Beberapa menu pembelajaran/permainan yang dapat diimplementasikan dalam kinestetik center, antara lain: merangkak, bergelantung, melompat, meronce manikmanik, dan bermain jumputan.

4. Visual-spasial center. Beberapa menu pembelajaran/permainan yang dapat diimplementasikan dalam visual-spasial center, antara lain: permainan warna, permainan menara, permainan menjiplak gambar, dan permainan navigasi arah (kanan-kiri).

5. Musical center. Beberapa menu pembelajaran/permainan yang dapat diimplementasikan dalam musical center, antara lain: bermain tepuk berirama, bermain "doremi", dan bermain tebak bunyi/suara.

6. Interpersonal center. Beberapa menu pembelajaran/permainan yang dapat diimplementasikan dalam interpersonal center, antara lain: bermain "rencana bersama", bermain mengenal perasaan, dan bermain tebak wajah. 
7. Intrapersonal center. Beberapa menu pembelajaran/permainan yang dapat diimplementasikan dalam intrapersonal center, antara lain: permainan "cita-citaku", permainan "aku", dan bermain fantasi/imajinasi.

8. Naturalis center. Beberapa menu pembelajaran/permainan yang dapat diimplementasikan dalam naturalis center, antara lain: permaian menjelajah alam, bermain "telur-ayam", bermain "pohon kesayanganku", dan bermain "mana buahku".

9. Eksistensialis center. Beberapa menu pembelajaran/permainan yang dapat diimplementasikan dalam eksistensialis center, antara lain: permainan pengandaian "melihat tanpa mata", permainan "pilih mana", dan permaainan "senjata atau teman".

\section{Pengorganisasian kurikulum Multiple Intelligence dengan kurikulum 2013 PAUD}

Pengembangan kurikulum 2013 PAUD berpedoman pada Permendikbud Nomor 146 Tahun 2014. Struktur kurikulum 2013 pendidikan anak usia dini merupakan pengorganisasian kompetensi inti, kompetensi dasar, muatan pembelajaran, program pengembangan dan beban belajar. Pada kurikulum multiple intelligence kompetensi inti, kompetensi dasar, dan muatan pembelajaran diorganisasikan dengan masing-masing kecerdasan majemuk. Pengoganisasian tersebut dapat dilihat dari gambar berikut:

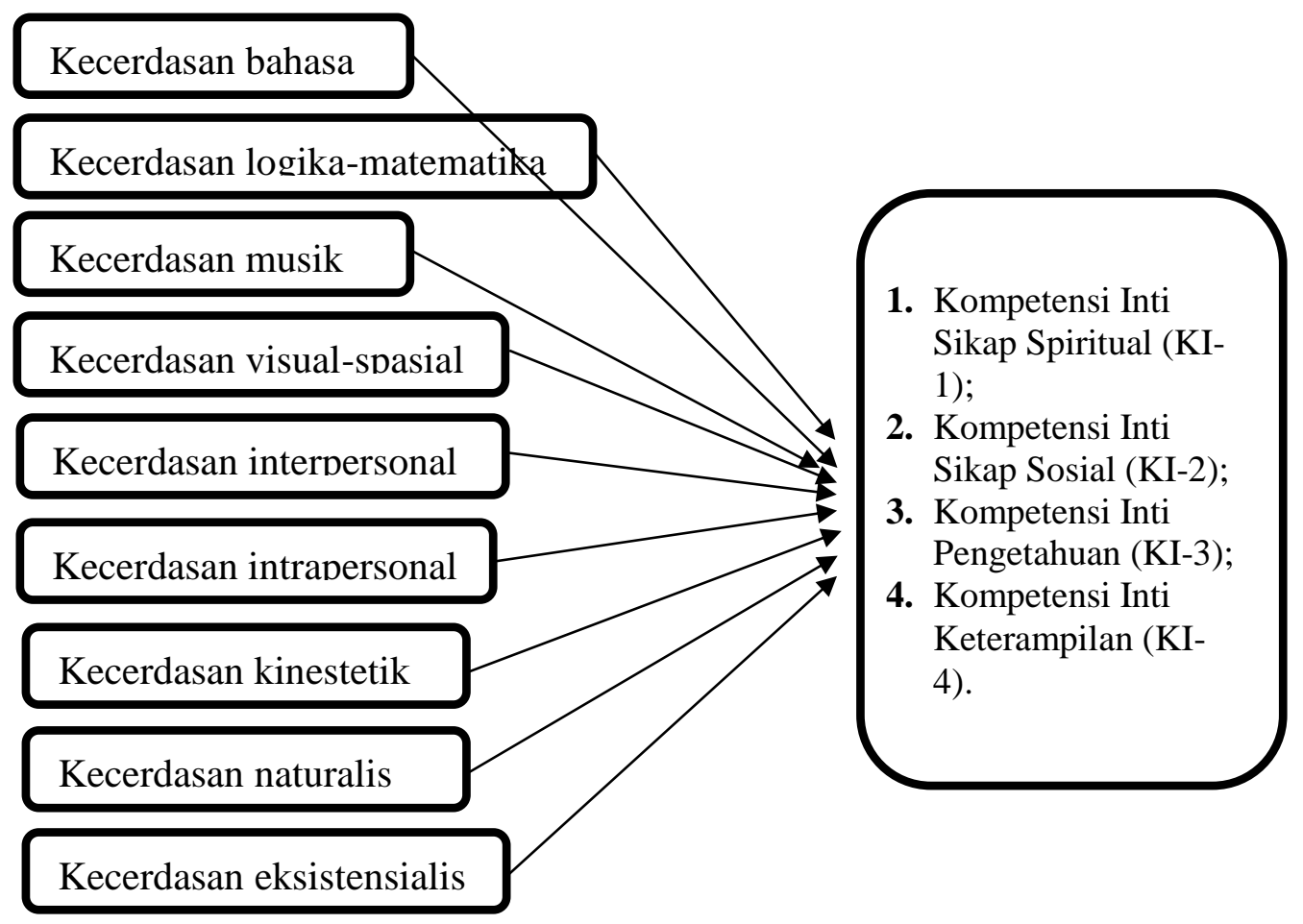

Gambar 2.

Pengorganisasian kurikulum M ultiple Intelligence dengan kurikulum 2013 PAUD

\section{Implikasi kurikulum Multiple Intelligence terhadap proses pembelajaran di PAUD}

Proses pembelajaran meliputi 3 tahap, yakni perencanaan, pelaksanaan, dan evaluasi pembelajaran. Berikut ini contoh Kerangka Rencanaan Pelaksanaan Pembelajaran Mingguan berbasis M ultiple Intelligence. 
RENCANA PELAKSANAAN PEMBELAJARAN MINGGUAN

\begin{tabular}{|c|c|c|c|c|c|}
\hline Hari & Senin & Selasa & Rabu & Kamis & Jumat \\
\hline Linguistic center & $\sqrt{ }$ & & $\sqrt{ }$ & & $\sqrt{ }$ \\
\hline Logical-math center & & $\sqrt{ }$ & & $\sqrt{ }$ & \\
\hline Kinestetic center & $\sqrt{ }$ & $\sqrt{ }$ & $\sqrt{ }$ & & $\sqrt{ }$ \\
\hline Visual-spasial center & & $\sqrt{ }$ & & $\sqrt{ }$ & \\
\hline M usic center & $\sqrt{ }$ & & & & \\
\hline Interpersonal center & $\sqrt{ }$ & & $\sqrt{ }$ & & $\sqrt{ }$ \\
\hline Intrapersonal center & & $\sqrt{ }$ & & $\sqrt{ }$ & \\
\hline Naturalis center & & & $\sqrt{ }$ & & $\sqrt{ }$ \\
\hline Eksistensialis center & & & & $\sqrt{ }$ & \\
\hline
\end{tabular}

Kerangka Rencana Pelaksanaan Pembelajaran Harian Berbasis Multiple Intelligence adalah sebagai berikut:

\section{RENCANA PELAKSANAAN PEMBELAJARAN HARIAN}

Hari/tanggal :

Minggu ke

Kelompok

Tema

Tujuan pembelajaran

Sumber/media

Kegiatan belajar

a. Linguistic center

b. Logical-mathematical center

c. Kinestetic center

d. Visual-spasial center

e. M usic center

f. Interpersonal center

g. Intrapersonal center

h. Naturalis center

i. Eksistensialis center

j. Prosedur penilaian

\section{Simpulan}

Pengembangan kurikulum adalah proses perencanaan, implementasi dan evaluasi yang dilakukan oleh tim pengembang kurikulum mencakup tujuan, materi, bahan ajar dan evaluasi yang digunakan sebagi pedoman pembelajaran suatu jenjang pendidikan. Pengembangan kurikulum Pendidikan Anak Usia Dini (PAUD) berbasis Multiple Intelligence merupakan sebuah upaya untuk memgembangkan tujuan, materi, metode, serta evaluasi dengan memperhatikan perkembangan M ultiple Intelligence masing-masing anak. Kurikulum ini merupakan kurikulum yang berpusat pada peserta didik dan memperhatikan berbedaan masing-masing peserta didik. 
Bicara tentang kurikulum PAUD tentu tidak lepas dari konsep DAP (Developmentally Appropriate Practice), dimana DAP adalah perencanaan yang bermakna dan sesuai dengan perkembangan anak sebagai penerapan pengetahuan mengenai perkembangan anak dalam lembaga PAUD. Oleh karena itu, penentuan tujuan, metode, materi dan evaluasi dalam kurikulum berbasis multiple intelligence didasarkan pada perkembangan mutiple intelligence masing-masing peserta didik dengan memperhatikan ageappropriate, individual appropriate, dan cultural appropriate.

Implikasi kurikulum PAUD berbasis multiple intelligence tetap memperhatikan kurikulum PAUD yang ditetapkan oleh pemerintah yakni kurikulum 2013 PAUD. Perumusan tujuan pembelajaran dalam kurikulum mutiple intelligence dengan mengintegrasikan perkembangan M ultiple Intelligence dengan 4 Kompetensi yakni kompetensi inti spiritual (KI 1), kompetensi inti sosial ( $\mathrm{KI} 2$ ), kompetensi inti pengetahuan ( $\mathrm{KI} 3$ ), dan kompetensi inti keterampilan (KI 4). $M$ ateri dan metode pembelajaran disajikan dengan pendekatan center sesuai dengan masingmasing kecerdasan, antara lain: linguistic center, musical center, visual-spasial center, kinestetic center, logical-mathematical center, intrapersonal center, interpersonal center, naturaliscenter, dan eksistensialis center. Adapun untuk penilaian perkembangan anak didik didasarkan pada indikator pencapaian tiap-tiap kecerdasan pada tiap usia.

\section{Referensi}

Bredekamp, Sue. (2006). Basics of D evelopmentally A ppropriate Practice. Washington: NAEYC. www.naeyc.org

Campbell, Linda, dkk. (2006). M etode Praktis Pembelajaran Berbasis M ultiple Intelligences.

Kostelnik, Marjorie J, et.al. (1999). Developmentally Appropriate Curriculum. N ew Jersey: Prentice-Hall, Inc.

Musfiroh, Tadkiroatun. (2008). Pengembangan Kecerdasan Majemuk. Jakarta: Universitas Terbuka.

Musfiroh, Tadkiroatun. (2005). Bermain Sambil Belajar dan M engasah Kecerdasan (Stimulasi M ultiple Intelligences Anak U sia Taman Kanak-Kanak). Jakarta: D epdiknas.

Nugraha, Ali. (2008). Kurikulum dan Bahan Belajar TK. Jakarta: Univeritas Terbuka

Permendikbud Nomor 146 Tahun 2014. Jakarta: Depsiknas.

Petersen, Sandra H. (2015). Kurikulum Pendidikan Anak Usia Dini Berbasis Pendekatan Antarpersonal (A-Relationship Based A pproach). Jakarta: Prenadamedia Group.

Sibel $\&$ Ibrahim, Ali. (2013). The effects of multiple intelligence theory based teaching on students'Achievement and retention of knowledge (example of the enzymes subject). International Journal on New Trends in Education and Their Implications, Vol. 4 (3). 